\title{
Meningkatnya Hasil Belajar IPA Siswa Melalui Model Problem Based Learning Berbantuan Media Audio Visual
}

\author{
Dw. Md. Andika Sujana ${ }^{1}$, I Gst. Ngurah Japa ${ }^{2}$, Luh Pt. Yasmiartini Yasa ${ }^{3}$ iD \\ ${ }^{1,2,3}$ Pendidikan Profesi Guru Sekolah Dasar, Universitas Pendidikan Ganesha, Singaraja, Indonesia \\ *Corresponding author:dode.pump@gmail.com, igustingurah.japa@undiksha.ac.id, putu.yasmiartini@gmail.com
}

\begin{abstract}
Abstrak
Pembelajaran jarak jauh membuat siswa tidak termotivasi untuk belajar karena jenuh dengan pembelajaran yang hanya menampilkan tugas dan bahan ajar melalui aplikasi WhatsApp tanpa ada penjelasan dari guru. Selain itu, hasil belajar IPA siswa kelas V dengan hasil belajar ranah kognitif belum optimal dan pembelajaran masih bersifat konvensional. Penelitian ini bertujuan untuk menganalisis peningkatan hasil belajar IPA melalui model problem based learning berbantuan media audio visual. Subjek penelitian yaitu siswa kelas V SD berjumlah 24 orang. Data dikumpulkan dengan tes berbentuk pilihan ganda yang berjumlah 20 butir dan lembar observasi aktivitas siswa. Data hasil belajar dan observasi aktivitas siswa dianalisis dengan metode analisis deskriptif kuantitatif yaitu persentase ketuntasan belajar dan pesentase observasi aktivitas siswa. Data diambil dari siklus I dan siklus II. Hasil penelitian ini menunjukkan terjadi peningkatan, pada siklus I rata-rata hasil belajar 72, persentase ketuntasan klasikal 67\%, dan persentase aktivitas siswa 57\%. Pada siklus II rata-rata hasil belajar 81,67, persentase ketuntasan klasikal 83,33\% dan persentase aktivitas siswa 74\%. Jadi model problem based learning berbantuan media audio visual dapat meningkatkan hasil belajar IPA kelas V. Implikasi penelitian ini dapat memberikan dampak pada hasil belajar siswa menjadi meningkat.
\end{abstract}

Kata kunci: PBL, hasil belajar, audio visual

\section{Abstract}

Distance learning makes students unmotivated to learn because they are bored with learning that only displays assignments and teaching materials through the WhatsApp application without any explanation from the teacher. Other than that of grade V's learning result in science subject matter along with the learning result in cognitive area was not yet optimal and the learning method was still conventional. The purpose of this research is for knowing the escalation of the science learning result through Problem Based Learning method in help of audio visual media. The research's subject is 24 primary students in grade $V$. The data was collected by using multiplication choice test which contained of 20 questions and students' activities observation sheets. The students' learning result and activities observation data were analyzed by using descriptive quantitative analysis method in form of learning achievement and students' activities observation percentages. The data was collected from first cycle and second cycle. The result of this research shows that there is an escalation. In the first cycle, the average of the learning result is 72, classical completeness percentage is $67 \%$, and students' activities percentage is 57\%. Meanwhile, in the second cycle, the average of the learning result is 81.67, and the classical completeness percentage is $83.33 \%$, and the students' activities percentage is $74 \%$. Thus, the problem based learning method in help of the audio visual media can be used to escalate grade V science learning result. The implications of this research can have an impact on student learning outcomes to increase.

Keywords: PBL, learning result, audio visual

$\begin{array}{ll}\text { History: } & \\ \text { Received } & \text { : 06 Mei } 2021 \\ \text { Revised } & : \text { 15 Mei } 2021 \\ \text { Accepted } & : \text { 30 Juni } 2021 \\ \text { Published } & : \text { 25 Juli } 2021\end{array}$

Publisher: Undiksha Press

Licensed: This work is licensed under

a Creative Commons Attribution 4.0 License

Published : 25 Juli 2021

\section{Pendahuluan}

Muatan IPA memegang peranan penting dalam kehidupan sehari-hari. Pembelajaran IPA merupakan pembelajaran yang menekankan pemberian pengalaman secara langsung yang membahas tentang alam dan kejadian yang ada di alam berdasarkan serangkaian proses ilmiah (Abhyasari, Kusmariyatni, \& Agustiana, 2020; Putra, Margunayasa, \& Wibawa, 2017; Tias, 2017). Ilmu pengetahuan yang terdiri dari kumpulan fakta, konsep, teori, dan hukum melalui proses ilmiah biasa disebut dengan IPA(Desstya, Novitasari, Razak, \& Sudrajat, 2018; R. Iskandar \& Kusmayanti, 2018). Ilmu pengetahuan yang mempelajari tentang alam 
tersusun secara sistematis melalui proses ilmiah yang dibangun berdasarkan sikap ilmiah dan hasilnya berupa produk ilmiah juga kerap disebut dengan IPA (Budiasa \& Gading, 2020; Erna, 2021; Kusumawati \& Kristin, 2021). Dapat disimpulkan IPA merupakan pembelajaran secara ilmiah membahas tentang alam berdasarkan kumpulan fakta, konsep, teori, dan hukum. Materi muatan pembelajaran IPA dipandang sebagai tahap awal untuk memberi bekal kemampuan agar siswa mampu berpikir kritis, kreatif, logis, dan berinisiatif dalam menghadapi berbagai isu di masyarakat yang diakibatkan oleh perkembangan teknologi dan ilmu pengetahuan. Dengan demikian, pendidikan IPA diharapkan dapat menjadi wahana bagi siswa untuk mempelajari diri sendiri, alam sekitar, prospek pengembangan lebih lanjut, dan penerapannya di dalam kehidupan sehari-hari. Cara guru mengemas pengalaman belajar sangat menentukan keberhasilan muatan pembelajaran IPA.

Masalah tersebut juga sejalan dengan penelitian sebelumnya yang menyatakan bahwa saat pembelajaran jarak jauh siswa tidak dapat bertatap muka secara langsung dengan guru maupun teman-temannya (Mutaqinah \& Hidayatullah, 2020; Sa'ria, Syuba, \& Ngazizah, 2021). Hal ini menyebabkan siswa merasa bosan dan tidak termotivasi dalam menerima ilmu pengetahuan. Akibatnya pembelajaran menjadi kurang berkesan, berarti, serta siswa sebagian besar tidak paham dengan muatan materi yang diperoleh. Seharusnya pembelajaran IPA di SD memberikan kesempatan kepada siswa untuk memecahkan rasa ingin tahunya. Hal ini dapat membantu siswa dalam melatih dan meningkatkan kemampuan bertanya, mandiri, dan mencari jawaban berdasarkan apa yang mereka ketahui sebagai bekal dalam memecahkan masalah serta mengembangkan dan meningkatkan cara berpikir mereka. Jadi, penyebab hasil belajar siswa rendah salah satunya yaitu pembelajaran masih kurang inovasi yang menyebabkan motivasi siswa dalam belajar semakin menurun.

Berdasakan hasil observasi pembelajaran IPA di SD diketahui bahwa nilai rata-rata belajar siswa dalam muatan IPA 63,3 dengan banyak siswa yang belum memenuhi KKM adalah 14 orang $(58,33 \%)$, sedangkan banyak siswa yang sudah memenuhi KKM adalah 10 orang $(41,67 \%)$. KKM yang berlaku di sekolah adalah 70. Rata-rata hasil belajar IPA siswa kelas V SD masih tergolong rendah. Setelah dilakukan refleksi terhadap siswa dan guru diketahui bahwa hasil belajar siswa menurun selama pandemi Covid-19 ini disebabkan pembelajaran jarak jauh membuat siswa tidak termotivasi untuk belajar karena jenuh dengan pembelajaran yang hanya menampilkan tugas dan bahan ajar melalui aplikasi WhatsApp tanpa ada penjelasan dari guru. Siswa pun tidak dapat berinteraksi langsung dengan guru maupun teman-temannya ketika belajar. Selain itu penerapan model pembelajaran yang kurang inovatif yang juga membuat hasil belajar siswa menjadi menurun. Jika masalah ini dibiarkan, maka akan berdapak terhadap hasil belajar IPA yang semakin rendah dan motivasi belajar siswa juga akan rendah, salah satu solusi yang bisa dilakukan adalah dengan penerapan model inovatif.

Salah satu model pembelajaran yang dapat diterapkan untuk mengatasi permasalahan ini adalah model problem based learning. Model Problem Based Learning (PBL) merupakan salah satu model pembelajaran yang inovatif sehingga mampu menjadikan siswa lebih aktif dalam memecahkan masalah pada bidang studi yang dipelajari (Fitriyanti, F, \& Zikri, 2020; Handayani \& Muhammadi, 2020; Indra \& Fitria, 2021). Model problem based learning mengenalkan gagasan-gagasan baru yang mendorong siswa untuk berpikir kreatif, imajinatif dan percaya diri (Rahman, Khaeruddin, \& Ristiana, 2020; Yasmini, 2021). Siswa dihadapkan pada suatu masalah nyata sehingga dapat memacunya untuk meneliti, menguraikan, dan mencari penyelesaian (Alfianiawati, Desyandri, \& Nasrul, 2019; Elma \& Asri, 2020). Sehingga dapat disimpulkan model pembelajaran problem based learning melatih siswa dalam berpikir kreatif, imajinatif untuk memecahkan suatu permasalahan yang nyata. Model PBL yang mengacu pada permasalahan membuat siswa menjadi terlatih dalam memahami sebuah konsep (Kurniawan, Parmiti, \& Kusmariyatni, 2020). Selain itu model problem based 
learning dapat meningkatkan hasil belajar siswa (Prasedari, Pujdawan, \& Suranata, 2019). Selanjutnya, model problem based learning memiliki dampak positif terhadap hasil belajar siswa yang semakin meningkat (Safrida \& Kistian, 2020). Jadi dengan diterapkanya model pembelajaran problem based learning siswa akan belajar aktif yang berdampak pada peningkatan hasil belajar.

Pelaksanaan model PBL sulit dilakukan secara utuh di sekolah dasar. Hal ini karena seperti yang kita ketahui bahwa siswa SD masih berada pada tahap operasional konkret dan masih sulit memahami konsep-konsep abstrak sehingga diperlukan bantuan media pembelajaran yang mampu menerjemahkan dan membimbing siswa dalam memahami suatu permasalahan atau materi. Media audio visual merupakan media yang mengandung unsur suara dan unsur gambar misalnya video, slide dan lain sebagainya (Dedy, 2020; Pradilasari, Gani, \& Khaldun, 2019; Suprianto, 2020). Media pembelajaran audio visual merupakan media modern yang sesuai dengan kemajuan ilmu pengetahuan dan teknologi, meliputi media yang dapat dilihat dan didengar (Nurparida \& Srirahayu, 2021). Media audio visual berfungsi sebagai media penyalur informasi atau pesan dengan menyajikan unsur gambar dan suara sehingga materi yang disampaikan menjadi lebih konkret dan jelas (Kahfi, Setiawati, Ratnawati, \& Saepuloh, 2021). Keterbaharuan penelitian ini yaitu menerapkan Model Problem Based Learning (PBL) berbantu media audio visual, maka dirumuskan penelitian yaitu meningkatkan hasil belajar IPA dengan menerapkan model pembelajaran model problem based learning berbantuan media audio visual siswa kelas V. Adanya penelitian ini diharapkan dapat membantu siswa dalam meningkatkan hasil belajar IPA.

\section{Metode}

Penelitian ini termasuk penelitian tindakan kelas (PTK), yaitu proses pengkajian masalah pembelajaran di dalam kelas melalui refleksi diri dalam upaya untuk memecahkan masalah tersebut dengan cara melakukan berbagai tindakan yang terencana dalam situasi nyata serta menganalisis setiap pengaruh dari perlakuan tersebut (Sanjaya, 2016:22). Pada penelitian ini tindakan yang diberikan adalah usaha untuk mengatasi masalah di dalam proses pembelajaran sehingga dapat meningkatkan hasil belajar IPA melalui pembelajaran dengan menggunakan model pembelajaran problem based learning berbantuan media audio visual. Berikut tahapan penelitian tindakan kelas yaitu: perencanaan, pelaksanaan, observasi, dan refleksi. Rancangan penelitiannya seperti pada Gambar 1.

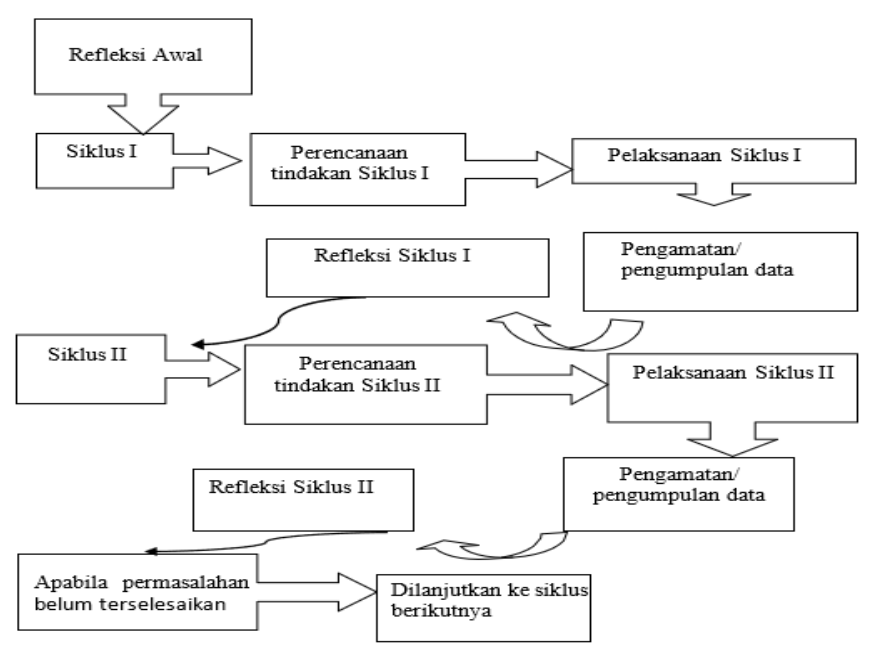

Gambar 1. Rancangan Penelitian Tindakan Kelas (Nurdin, 2016) 
Subjek penelitian tindakan kelas ini adalah siswa kelas V SD yang berjumlah 24 orang yang terdiri dari 11 laki-laki dan 13 perempuan. Data pada penelitian ini dikumpulkan dengan beberapa metode pengumpulan data yang disesuaikan dengan kebutuhan bentuk data yang dinginkan, data yang diperoleh haruslah valid dan reliabel. Adapun metode pengumpulan data dalam penelitian ini yaitu berupa tes dan lembar observasi

Lembar observasi yang digunakan dalam penelitian ini adalah lembar pengamatan berupa aktivitas siswa. Lembar pengamatan ini merupakan lembar observasi yang berisi indikator-indikator yang harus dilaksanakan oleh siswa, dengan tujuan hasil belajar yang diharapkan dapat tercapai secara optimal. Observasi dilakukan setiap kali pertemuan pada siklus I dan siklus II. Instrumen pengumpulan data aktivitas siswa terdiri dari 5 indikator dan setiap indikator terdiri dari 3 deskriptor. Berikut ini indikator aktivitas siswa yaitu: antusiasme siswa dalam mengikuti pembelajaran dengan menggunakan model problem based learning, aktivitas siswa dalam memberikan pendapat, aktivitas siswa dalam presentasi, interaksi siswa dengan guru, dan partisipasi siswa dalam menyimpulkan hasil belajar.

Untuk menentukan secara jelas ruang lingkup penelitian dan sebagai petunjuk dalam menulis butir instrumen hasil belajar, maka harus ditentukan kisi-kisi dari instrumen yang akan disusun. Kisi-kisi instrumen disusun berdasarkan objek pelaksanaan tindakan yang dilakukan di kelas. Adapun kisi-kisi instrumen dapat dilihat pada Tabel 1.

Tabel 1. Kisi-Kisi Instrumen Tes Hasil Belajar

\begin{tabular}{|c|c|c|c|c|}
\hline $\begin{array}{l}\text { Kompetensi } \\
\text { Dasar }\end{array}$ & & Indikator & No Soal & Siklus \\
\hline \multirow{22}{*}{$\begin{array}{l}3.7 \\
\text { Menganalis } \\
\text { is pengaruh } \\
\text { kalor } \\
\text { terhadap } \\
\text { perubahan } \\
\text { suhu dan } \\
\text { wujud } \\
\text { benda } \\
\text { dalam } \\
\text { kehidupan } \\
\text { sehari-hari }\end{array}$} & 3.7 .1 & Menganalisis sifat-sifat benda padat, cair dan & $1,2,4,5$ & \multirow{10}{*}{$\begin{array}{l}\text { Siklus } \\
\text { I }\end{array}$} \\
\hline & & & & \\
\hline & 3.7 .2 & $\begin{array}{l}\text { Mengaitkan sifat-sifat benda padat, cair, dan gas } \\
\text { dalam kehidupan sehari-hari }\end{array}$ & 3,16 & \\
\hline & 3.7 .3 & Menganalisis perubahan wujud benda mencair, & $6,8,17,1$ & \\
\hline & \multirow{3}{*}{3.7 .4} & membeku dan menguap & \multirow{3}{*}{$\begin{array}{c}8 \\
7,9,10,1 \\
9,20\end{array}$} & \\
\hline & & membeku, dan menguap dalam kehidupan & & \\
\hline & & sehari-hari & & \\
\hline & 3.7 .5 & Menganalisis perubahan wujud benda & 11,14 & \\
\hline & & mengembun & & \\
\hline & 3.7 .6 & Menemukan peristiwa mengembun dalam & 12,13 & \\
\hline & & kehidupan sehari-hari & & \\
\hline & 3.7 .7 & $\begin{array}{l}\text { Menganalisis kalor dapat mengubah suhu } \\
\text { benda. }\end{array}$ & $1,2,3,4$ & \\
\hline & 3.7 .8 & Menemukan peristiwa yang menunjukkan kalor & $5,6,7,8$ & \\
\hline & & dapat mengubah suhu benda dalam kehidupan & & \\
\hline & & sehari-hari. & & \\
\hline & 3.7 .9 & $\begin{array}{l}\text { Menganalisis perubahan wujud benda pada } \\
\text { peristiwa menyublim }\end{array}$ & $9,10,11$ & Siklus \\
\hline & 3.7 .10 & Menvebutkan contoh-contoh peristiwa & $12,13,1$ & \\
\hline & & menyublim dalam kehidupan sehari-hari & 4 & \\
\hline & 3.7 .11 & Menganalisis peristiwa mengkristal & $15,16,1$ & \\
\hline & & & 7 & \\
\hline & 3.7 .12 & Menyebutkan contoh-contoh peristiwa & $18,19,2$ & \\
\hline & & mengkristal dalam kehidupan sehari-hari & 0 & \\
\hline
\end{tabular}


Adapun langkah-langkah untuk menganalisis data hasil belajar menggunakan analisis deskriptif kuantitatif dengan mencari rata-rata hasil belajar dan persentase ketuntasan klasikal. Anaslis rata-rata hasil belajar yang telah diperoleh kemudian dikonversi pada Tabel 2 dan persentase ketuntasan klasikal siswa dikonversikan ke dalam Tabel 3.

Tabel 2. Skala Penskoran Rata-Rata Hasil Belajar

\begin{tabular}{cc}
\hline Interval & Kriteria \\
\hline $85-100$ & Sangat tinggi \\
$70-84$ & Tinggi \\
$55-69$ & Sedang \\
$40-54$ & Kurang \\
$00-39$ & Sangat kurang \\
\hline
\end{tabular}

Tabel 3. Persentase Ketuntasan Klasikal Siswa

\begin{tabular}{cc}
\hline Nilai/Persentase & Kriteria \\
\hline $85 \%-100 \%$ & Sangat tinggi \\
$70 \%-84 \%$ & Tinggi \\
$55 \%-69 \%$ & Sedang \\
$40 \%-54 \%$ & Rendah \\
$0 \%-39 \%$ & Sangat rendah \\
\hline
\end{tabular}

Adapun langkah-langkah untuk menganalisis data observasi aktivitas siswa yaitu melalui penilaian aktivitas siswa diperoleh dari hasil observasi langsung. Penilaian ini dilakukan ketika sedang belajar, di observasi secara langsung oleh observer. Adapun teknik penilaian untuk aktivitas belajar siswa terdiri dari 5 indikator, setiap indikator terdiri dari 3 deskriptor dan mempunyai skala 1 sampai 4. Penskoran dilakukan dengan cara sebagai berikut: skor 1 diberikan jika $\mathrm{x} \leq 25 \%$ siswa melakukan deskriptor yang dimaksud (1-6 orang), skor 2 diberikan jika $26 \% \leq \mathrm{x} \leq 50 \%$ siswa melakukan deskriptor yang dimaksud (712 orang), skor 3 diberikan jika $51 \% \leq \mathrm{x} \leq 74 \%$ siswa melakukan deskriptor yang dimaksud (13-18 orang), skor 4 diberikan jika $x \geq 75 \%$ siswa melakukan deskriptor yang dimaksud (1924 orang). Data aktivitas belajar siswa di atas dianalisis dengan cara menghitung persentase skor rata-rata aktivitas siswa. Setelah mendapat persentase skor rata-rata aktivitas siswa, maka hasilnya dikonversikan ke dalam pedoman konversi Tabel 4.

Tabel 4. Persentase Skor Rata-Rata Aktivitas Belajar Siswa

\begin{tabular}{cc}
\hline Nilai/Persentase & Kriteria \\
\hline $85 \%-100 \%$ & Sangat Aktif \\
$70 \%-84 \%$ & Aktif \\
$55 \%-69 \%$ & Cukup Aktif \\
$40 \%-54 \%$ & Kurang Aktif \\
$0 \%-39 \%$ & Sangat Kurang \\
\hline
\end{tabular}

Diadaptasi dari (Agung, 2010)

Keberhasilan suatu penelitian dapat dilihat dari kemajuan hasil belajar yang dicapai oleh siswa sesuai dengan KKM yang ditetapkan oleh sekolah yaitu memperoleh nilai secara individu minimal 70. Adapun indikator keberhasilan yang diinginkan oleh peneliti dalam penelitian ini yaitu rata-rata hasil belajar muatan IPA siswa berada dalam kategori tinggi, persentase ketuntasan klasikal minimal $80 \%$ dari jumlah siswa pada akhir siklus dalam 
penelitian ini, penelitian ini dikatakan berhasil bila persentase aktivitas belajar siswa mencapai kategori aktif.

\section{Hasil dan Pembahasan}

Pada penelitian ini, data hasil belajar siswa diperoleh dari evaluasi yang dilakukan pada setiap akhir siklus. Sedangkan data aktivitas siswa dalam proses pembelajaran di kelas diperoleh dari hasil lembar observasi aktivitas siswa. Kegiatan siklus I dilakukan sebanyak 3 kali pertemuan. Pertemuan pertama membahas tentang mengaitkan sifat-sifat benda, cair, padat, dan gas dalam kehidupan sehari-hari. Pertemuan kedua membahas tentang perubahan wujud benda mencair, membeku, dan menguap. Pertemuan ketiga membahas tentang perubahan wujud benda pada peristiwa mengembun.

Adapun hasil aktivitas siswa setelah diadakannya pelaksanaan kegiatan belajar mengajar sesuai dengan rencana pembelajaran yang telah disusun dengan menerapkan model problem based learning yaitu persentase rata-rata aktivitas siswa pada siklus I berkategori cukup aktif dengan persentase aktivitas $57 \%$. Hal ini menunjukkan indikator keberhasilan penelitian tentang aktivitas siswa belum tercapai karena aktivitas belajar siswa belum mencapai kategori aktif. Pada pertemuan satu siklus I persentase aktivitas siswa adalah 55\% dengan kategori cukup aktif. Aktivitas siswa dalam memberikan pendapat masih kurang aktif, siswa merasa tidak percaya diri untuk menyampaikan pendapatnya. Dalam kegiatan melakukan percobaan beberapa siswa tidak melakukan percobaan tersebut dikarenakan percobaan yang dilakukan cukup berbahaya yang menggunakan api. Siswa tersebut hanya menyimak percobaan yang dilakukan oleh temannya. Pada saat kegiatan pembelajaran berlangsung beberapa siswa merasakan kejenuhan dan kurang fokus terhadap materi yang disampaikan. Pada pertemuan dua siklus I persentase aktivitas siswa adalah 57\% dengan kategori cukup aktif. Pada pertemuan dua masih terlihat aktivitas siswa dalam memberikan pendapat masih kurang aktif, namun beberapa sudah percaya diri dalam menyampaikan pendapatnya. Pada pertemuan tiga, persentase aktivitas adalah $60 \%$ dengan kategori cukup aktif. Dibandingkan dengan pertemuan pertama dan kedua aktivitas siswa pada pertemuan ketiga sudah mengalami peningkatan. Terlihat siswa dengan antusias angkat tangan untuk menjawab pertanyaan-pertanyaan yang diberikan guru. Siswa sudah berani menyampaikan pendapatnya namun perlu ditingkatkan lagi. Adapun kegiatan evaluasi, dilakukan pada pertemuan akhir siklus I. Evaluasi dilakukan untuk mengetahui pemahaman siswa setelah diterapkannya tindakan model problem based learning berbantuan media audio visual oleh peneliti.

Selain menganalisis aktivitas siswa, persentase ketuntasan klasikal dan rata-rata hasil belajar siswa juga dianalisis. Rata-rata hasil belajar muatan IPA berdasarkan data yang diperoleh yaitu 72 yang jika dikonversikan dalam kriteria hasil belajar muatan IPA sudah termasuk dalam kriteria tinggi. Nilai tertinggi yang diperoleh siswa pada pembelajaran ini adalah 85, sedangkan nilai terendahnya adalah 50. Terdapat 16 siswa dengan persentase ketuntasan belajar (67\%) yang memperoleh nilai di atas atau sama dengan KKM. Sedangkan 8 siswa (33\%) masih memperoleh nilai di bawah KKM. Sehingga hasil belajar muatan IPA pada siklus I belum memenuhi kriteria keberhasilan penelitian tindakan kelas, karena persentase ketuntasan klasikal minimal belum $80 \%$ dari jumlah siswa pada akhir siklus dalam penelitian ini. Merujuk dari hasil tersebut, maka penelitian dilanjutkan pada pelaksanaan siklus II untuk membuktikan apakah memang benar penerapan model problem based learning berbantuan media audio visual membuat aktivitas dan hasil belajar siswa kelas $\mathrm{V}$ meningkat.

Kegiatan siklus II dilakukan sebanyak 3 kali pertemuan. Pertemuan pertama membahas tentang kalor dapat mengubah suhu benda. Pertemuan kedua membahas tentang perubahan wujud benda pada peristiwa menyublim. Pertemuan ketiga membahas tentang 
perubahan wujud benda pada peristiwa pengkristalan. Kegiatan yang dilakukan pada tahap pelaksanaan adalah melaksanakan kegiatan belajar mengajar sesuai dengan rencana pembelajaran yang telah disusun dengan menerapkan model problem based learning berbantuan media audio visual. Dilakukannya kegiatan observasi untuk mengetahui apa saja kekurangan-kekurangan yang ada dalam kegiatan pembelajaran yang menjadi bahan refleksi bagi peneliti untuk diperbaiki pada penerapan model problem based learning berbantuan media audio visual. Aktivitas siswa diobservasi selama kegiatan pembelajaran berlangsung.

Adapun hasil aktivitas siswa setelah diadakannya pelaksanaan kegiatan belajar mengajar sesuai dengan rencana pembelajaran yang telah disusun dengan menerapkan model problem based learning yaitu persentase rata-rata aktivitas siswa pada siklus II berkategori aktif dengan persentase $74 \%$. Hal ini menunjukkan indikator keberhasilan penelitian tentang aktivitas siswa sudah tercapai. Berikut temuan-temuan yang didapatkan pada penelitian siklus II. Pertemuan satu siklus II, setelah melakukan refleksi terhadap pembelajaran di siklus I kegiatan pembelajaran pada siklus II mengalami peningkatan yang baik. Dilihat dari pembelajaran daring menggunakan model problem based learning berbantuan media audio visual sudah dapat berjalan dengan baik, siswa sudah mulai aktif dalam menyampaikan pendapat, menjawab pertanyaan, dan bertanya kepada guru terkait materi yang belum dimengerti hal itu dikarenakan guru memberikan reward terhadap siswa yang mau berpendapat dan bertanya. Berdasarkan pertemuan satu siklus II dapat diketahui persentase aktivitas siswa sebesar $72 \%$ dengan kategori aktif. Pada pertemuan dua siklus II aktivitas siswa mengalami peningkatan persentase sebesar $73 \%$ dengan kategori aktif. Ketika siswa merasakan jenuh, guru melakukan ice breaking sehigga siswa kembali fokus terhadap pembelajaran. Selain itu pemberian video percobaan mampu menarik perhatian siswa, sehingga siswa dapat mengembangkan kemampuan berpikir tingkat tinggi dan siswa merasa tertantang untuk menyelesaikan masalah yang disampaikan guru. Pada peremuan tiga siklus II aktivitas mengalami peningkatan yang lebih baik. Terlihat antusias siswa semakin meningkat, siswa berebutan untuk menyampaikan pendapat dan bertanya kepada guru. Hal itu dikarenakan guru memberikan reward terhadap siswa yang mau berpendapat dan bertanya. Berdasarkan hasil observasi aktivitas siswa tersebut diperoleh persentase aktivitas siswa pada pertemuan ketiga sebesar $77 \%$ dengan kategori aktif. Semua hasil observasi pada siklus II menjadi bahan refleksi untuk kegiatan pembelajaran di kelas. Adapun kegiatan evaluasi, dilakukan pada pertemuan akhir siklus II. Evaluasi dilakukan untuk mengetahui pemahaman siswa setelah diterapkannya tindakan model problem based learning berbantuan media audio visual oleh peneliti.

Selain menganalisis aktivitas siswa, hasil persentase ketuntasan klasikal dan rata-rata hasil belajar siswa juga dianalisis. Hasil belajar muatan IPA pada siklus II diperoleh rata-rata hasil belajar pengetahuan siswa adalah 81,67 yang jika dikonversikan dalam kriteria hasil belajar muatan IPA sudah termasuk dalam kriteria tinggi. Nilai tertinggi yang diperoleh siswa pada pembelajaran ini adalah 100, sedangkan nilai terendahnya adalah 50. Terdapat 20 siswa $(83,33 \%)$ yang memperoleh nilai di atas KKM. Sedangkan 4 siswa $(16,67 \%)$ masih memperoleh nilai di bawah KKM. Sehingga hasil belajar muatan IPA pada siklus II memenuhi kriteria keberhasilan penelitian tindakan kelas, karena persentase rata-rata hasil belajar muatan IPA siswa berada dalam kategori tinggi dan persentase ketuntasan klasikal minimal sudah di atas $80 \%$ dari jumlah siswa pada akhir siklus dalam penelitian ini. Berdasarkan hasil pengamatan selama melaksanakan tindakan untuk 3 kali pertemuan per siklus, bahwa hampir sebagian siswa sudah mampu memahami dan mengikuti pembelajaran secara daring melalui aplikasi Zoom Meeting dan WhatsApp dengan menggunakan model pembelajaran problem based learning berbantuan media audio visual. Hal ini dapat didukung oleh hasil observasi atau pengamatan dari keaktifan dan sikap siswa ketika mengikuti pembelajaran, persentase aktivitas siswa dalam kegiatan pembelajaran juga meningkat dari 
siklus I ke siklus II yaitu 57\% menjadi 74\%. Sehingga PTK dinyatakan telah berhasil pada siklus II. Adapun hasil analisis rata-rata hasil belajar siswa, persentase ketuntasan klasikal siswa dan persentase aktivitas siswa siklus I dan siklus II dapat dilihat pada Tabel 5.

Tabel 5. Rekapitulasi Hasil Siklus I dan Siklus II

\begin{tabular}{llcc}
\hline No & \multicolumn{1}{c}{ Aspek yang di nilai } & Siklus I & Siklus II \\
\hline 1 & Jumlah siswa kelas V & 24 Orang & 24 Orang \\
2 & Jumlah siswa yang mengikuti pembelajaran & 24 Orang & 24 Orang \\
3 & Jumlah siswa yang mengikuti tes & 24 Orang & 24 Orang \\
4 & Nilai tertinggi & 85 & 100 \\
5 & Nilai terendah & 50 & 50 \\
6 & Rata-rata & 72 & 81,67 \\
7 & Jumlah siswa tuntas & 16 & 20 \\
8 & Jumlah siswa tidak tuntas & 8 & 4 \\
9 & Persentase rata-rata aktivitas siswa & $57 \%$ & $74 \%$ \\
10 & Persentase ketuntasan klasikal & $67 \%$ & $83,33 \%$ \\
\hline
\end{tabular}

Berdasarkan Tabel 5, peningkatan hasil belajar siswa dari siklus I menuju siklus II yaitu rata-rata hasil belajar sebesar 9.67, persentase rata-rata aktivitas siswa meningkat sebesar $17 \%$, dan ketuntasan klasikal sebanyak 16,33\%. Peningkatan hasil belajar IPA siswa kelas $\mathrm{V}$ tersebut menunjukkan bahwa dengan menerapkan model pembelajaran problem based learning berbantuan media audio visual, siswa dapat memecahkan permasalahan sesuai dengan materi pembelajaran, keaktifan siswa juga terlihat meningkat dengan adanya pemberian video pembelajaran yang lebih menarik dan sesuai dengan materi serta karakteristik siswa. Kemampuan berpikir tingkat tinggi yang dimiliki siswa, dapat melatih pola pikir untuk lebih kreatif dan inovatif dalam memecahkan permasalahan yang diberikan.

Model pembelajaran problem based learning dapat meningkatkan hasil belajar siswa khususnya muatan pelajaran IPA kelas V SD karena disebabkan oleh beberapa faktor yaitu yang pertama penerapan model pembelajaran problem based learning dapat melatih siswa berpikir tingkat tinggi untuk menyelesaikan suatu masalah, sehingga siswa menjadi tertantang dan termotivasi dalam belajar serta mencari informasi terkait dengan masalah yang diajukan guru. Ketika siswa telah menemukan jawaban terhadap masalah yang diajukan guru, siswa akan mendapatkan kepuasan dan meningkatkan motivasi belajar dari dalam dirinya. Model problem based learning dilaksanakan secara sistematis sehingga bisa melatih keterampilan berpikir tingkat tinggi siswa dalam memahami dan menyelesaikan masalah (Handayani \& Muhammadi, 2020). Kedua, penerapan model pembelajaran problem based learning tidak hanya memahami dan menyelesaikan masalah namun siswa juga bisa menggali pengetahuan dan keterampilannya sendiri. Penerapan model $P B L$ dapat membantu siswa mengembangkan pemahaman konsep matematis dan pola berpikir kritis sehingga siswa dituntun untuk dapat membangun sendiri pengetahuan dalam bentuk konsep sehingga dapat menyelesaikan permasalahan yang terdapat dalam kehidupan sehari-hari (Alwardah, Sitorus, \& Nuraini, 2021; Nurrohma \& Adistana, 2021).

Ketiga, penerapan model pembelajaran problem based learning yang dikombinasikan dengan media audio visual mampu menarik perhatian siswa, sehingga siswa dapat mengembangkan kemampuan berpikir tingkat tinggi dan siswa pun merasa tertantang untuk menyelesaikan masalah yang disampaikan guru. Penggunaan media pembelajaran audio visual juga sangat membantu guru untuk meningkatkan pemahaman siswa. Penyajian media pembelajaran audio visual yang menarik bagi siswa dapat menumbuhkan motivasi dari luar diri (ekstrinsik). Media audio visual akan membuat pembelajaran menjadi lebih jelas 
maknanya, tidak membosankan, dan adanya kegiatan aktif dari siswa seperti mengamati, menganalisis dan menyimpulkan sehingga dapat melatih kemampuan berpikir tingkat tinggi siswa. Media audio visual berfungsi sebagai media penyalur informasi atau pesan dengan menyajikan unsur gambar dan suara sehingga materi yang disampaikan menjadi lebih konkret, dan jelas sehingga pada akhirnya siswa menjadi lebih mudah memahami materi yang diajarkan (Angreiny, Muhiddin, \& Nurlina, 2020; Kahfi et al., 2021).

Penemuan ini juga didukung dengan beberapa penelitian sebelumnya yang menyatakan bahwa terdapat pengaruh model pembelajaran problem based learning berbantuan media visual terhadap kemampuan berpikir kritis dan hasil belajar IPA siswa SD (Devi \& Bayu, 2020). Penerapan model pembelajaran problem based learning berbantu media audio visual dapat meningkatkan hasil belajar dan membuat suasana pembelajaran yang menarik dan menyenangkan siswa kelas IV SDN Jawisari Kendal (Jannah, Rahmawati, \& Reffiane, 2020). Penerapan model pembelajaran $P B L$ dapat meningkatkan hasil belajar pada materi pecahan siswa kelas $\mathrm{V}$ sekolah dasar penelitian (Anjani, Sulianto, \& Untari, 2021). Pembelajaran menggunakan media audio visual dapat meningkatkan aktivitas dan penguasaan konsep IPA peserta didik (J. Iskandar, 2020). Penerapan model pembelajaran problem based learning berbantuan media audio visual memiliki kelebihan yaitu siswa berperan aktif dalam pembelajaran disebabkan siswa dapat memecahkan suatu masalah yang nyata, dapat berlatih berpikir tingkat tinggi, pembelajaran bermakna, lebih berpusat kepada siswa dan kelebihan video yang diantaranya bersifat menyenangkan bagi siswa, mampu memberikan sajikan informasi yang konkret.

\section{Simpulan}

Penerapan model pembelajaran problem based learning berbantuan media audio visual dapat meningkatkan hasil belajar IPA siswa karena model problem based learning dapat melatih siswa berpikir tingkat tinggi untuk menyelesaikan suatu masalah, sehingga siswa menjadi tertantang dan termotivasi dalam belajar serta mencari informasi terkait dengan masalah yang diajukan guru. Ketika siswa telah menemukan jawaban terhadap masalah yang diajukan guru, siswa akan mendapatkan kepuasan dan meningkatkan motivasi belajar dari dalam dirinya. Penerapan model pembelajaran problem based learning yang dikombinasikan dengan media audio visual mampu menarik perhatian siswa, sehingga siswa dapat mengembangkan kemampuan berpikir tingkat tinggi dan siswa pun merasa tertantang untuk menyelesaikan masalah yang disampaikan guru. Penggunaan media pembelajaran audio visual juga sangat membantu guru untuk meningkatkan pemahaman siswa.

\section{Daftar Rujukan}

Abhyasari, N. P., Kusmariyatni, N. N., \& Agustiana, I. G. A. T. (2020). Pengaruh Pembelajaran Berpendekatan Saintifik Berbasis Masalah Terhadap Disiplin dan Hasil Belajar IPA. Mimbar PGSD Undiksha, 8(1), 111-122. Retrieved from https://ejournal.undiksha.ac.id/index.php/JJPGSD/article/view/24547.

Agung, A. A. G. (2010). Pengantar Evaluasi Pendidikan. Singaraja: Undiksha.

Alfianiawati, T., Desyandri, \& Nasrul. (2019). Pengaruh Penggunaan Model Problem Based Learning (PBL) terhadap Hasil Belajar Siswa dalam Pembelajaran IPS di Kelas V SD. Ejournal Pembelajaran Inovasi: Jurnal Ilmiah Pendidikan Dasar, 7(3), 1-10. Retrieved from http://ejournal.unp.ac.id/students/index.php/pgsd/article/view/5400/2795.

Alwardah, N., Sitorus, K., \& Nuraini. (2021). Penerapan Model Pembelajaran Problem Based Learning (PBL) Menggunakan Media Power Point Interaktif Terhadap Hasil Belajar Peserta Didik. Jurnal IPA Terpadu, 4(2), 53-62. Retrieved from 
https://ojs.unm.ac.id/ipaterpadu/article/view/18927.

Angreiny, D., Muhiddin, M., \& Nurlina, N. (2020). Pengaruh Penggunaan Media Audio Visual Terhadap Motivasi dan Hasil Belajar IPA Siswa Kelas V SD Negeri Bontoramba. Edumaspul-Jurnal Pendidikan, 4(1), 42-49. https://doi.org/10.46965/ja.v18i1.43.

Anjani, N. D., Sulianto, J., \& Untari, M. F. A. (2021). Peningkatan Hasil Belajar Materi Pecahan dengan Menerapkan Model Problem Based Learning dengan Media Manipulatif. Journal of Education Action Research, 5(2), 246-253. https://doi.org/10.23887/jear.v5i2.33136.

Budiasa, P., \& Gading, I. K. (2020). Model Pembelajaran Inkuiri Terbimbing Berbantuan Media Gambar Terhadap Keaktifan dan Hasil Belajar IPA. Mimbar PGSD Undiksha, 8(2), 253-263. Retrieved from https://ejournal.undiksha.ac.id/index.php/JJPGSD/article/view/26526.

Dedy, S. (2020). Implementasi Model Pembelajaran Direct Instruction (DI) Berbantuan Media Audio Visual untuk Meningkatkan Hasil Belajar IPA pada Peserta Didik Kelas V SDN-1 Langkai Palangka Raya. Pedagogik Jurnal Pendidikan, 15(1), 1-9. Retrieved from http://journal.umpalangkaraya.ac.id/index.php/pedagogik/article/view/1277/1126.

Desstya, A., Novitasari, I. I., Razak, A. F., \& Sudrajat, K. S. (2018). Refleksi Pendidikan IPA Sekolah Dasar di Indonesia (Relevansi Model Pendidikan Paulo Freire dengan Pendidikan IPA di Sekolah Dasar). Profesi Pendidikan Dasar, 1(1), 1. https://doi.org/10.23917/ppd.v1i1.2745.

Devi, P. S., \& Bayu, G. W. (2020). Berpikir Kritis dan Hasil Belajar IPA Melalui Pembelajaran Problem Based Learning Berbantuan Media Visual. Mimbar PGSD Undiksha, 8(2), 238-252. Retrieved from https://ejournal.undiksha.ac.id/index.php/JJPGSD/article/view/26525.

Elma, P. G. G. J., \& Asri, I. G. A. A. S. (2020). Pengaruh Model Problem Based Learning Berorientasi Tri Hita Karana Terhadap Kompetensi Pengetahuan IPA. Jurnal Ilmiah Pendidikan Profesi Guru, 3(2), 486-494. https://doi.org/10.23887/jippg.v3i3.29698.

Erna, E. N. (2021). Meningkatkan Hasil Belajar IPA Siswa Kelas VI pada Materi Gaya dan Gerak Menggunakan Metode Demonstrasi Di SDK Watupedar. Jurnal Pendidikan Guru, 2(1), 1-6. Retrieved from http://150.107.142.43/index.php/jpg/article/view/4095/2337.

Fitriyanti, F, F., \& Zikri, A. (2020). Peningkatan Sikap dan Kemampuan Berpikir Ilmiah Siswa melalui Model PBL di Sekolah Dasar. Jurnal Basicedu, 4(2), 491-497. https://doi.org/10.31004/basicedu.v4i2.376.

Handayani, R. H., \& Muhammadi. (2020). Penerapan Model Problem Based Learning untuk Melatih Higher Order Thinking Skill Siswa Sekolah Dasar. Jurnal Pendidikan Tambusai, 4(2), 1494-1499. https://doi.org/10.36456/inventa.2.1.a1627.

Indra, W., \& Fitria, Y. (2021). Pengembangan Media Games IPA Edukatif Berbantuan Aplikasi Appsgeyser Berbasis Model PBL untuk Meningkatkan Karakter Peduli Lingkungan Siswa Sekolah Dasar. JEMS: Jurnal Edukasi Matematika Dan Sains, 9(1), 59-66. https://doi.org/10.25273/jems.v9i1.8654.

Iskandar, J. (2020). Upaya Meningkatkan Penguasaan Konsep IPA melalui Penggunaan Media Audio Visual Improving. Journal of Biology Education Research, 1(1), 89-97. Retrieved from https://e-journal.metrouniv.ac.id/index.php/AlJahiz/article/view/3144/2087.

Iskandar, R., \& Kusmayanti, I. (2018). Pendekatan Science Technology Society IPA di Sekolah Dasar. Jurnal Ilmiah Pendidikan Guru Sekolah Dasar, 2(2), 200-215. Retrieved

from 
Jannah, A. R., Rahmawati, I., \& Reffiane, F. (2020). Keefektifan Model PBL Berbantu Media Audio-Visual Terhadap Hasil Belajar Tema Indahnya Keberagaman Di Negeriku. Mimbar PGSD Undiksha, 8(3), 342-350. Retrieved from https://ejournal.undiksha.ac.id/index.php/JJPGSD/article/view/28951/16495.

Kahfi, M., Setiawati, W., Ratnawati, Y., \& Saepuloh, A. (2021). Efektivitas Pembelajaran Kontekstual dengan Menggunakan Media Audiovisual dalam Meningkatkan Motivasi dan Prestasi Siswa pada Pembelajaran IPS Terpadu. Jurnal Imliah Mandala Education, 7(1), 84-89. Retrieved from http://ejournal.mandalanursa.org/index.php/JIME/article/view/1636/1474.

Kurniawan, I. K., Parmiti, D., \& Kusmariyatni, N. (2020). Pembelajaran IPA dengan Model Problem Based Learning Berbantuan Media Audio Visual Meningkatkan Pemahaman Konsep Siswa. Jurnal Edutech Undiksha, 8(2), 80. https://doi.org/10.23887/jeu.v8i2.28959.

Kusumawati, V. V., \& Kristin, F. (2021). Meta Analisis Penerapan Model Pembelajaran Two Stay Two Stray Terhadap Peningkatan Hasil Belajar IPA Siswa Sekolah Dasar. Jurnal Pendidikan Dasar Perkhasa, 7(April), 25-34. https://doi.org/10.31932/jpdp.v7i1.1088.

Mutaqinah, R., \& Hidayatullah, T. (2020). Implementasi Pembelajaran Daring (Program BDR) Selama Pandemi Covid-19 di Provinsi Jawa Barat. Jurnal Petik, 6(2), 86-95. https://doi.org/10.31980/jpetik.v6i2.869.

Nurdin, H. S. (2016). Guru Profesional dan Penelitian Tindakan Kelas. Journal of Education Studies, $1(1), \quad 1-12 . \quad$ Retrieved from https://ejournal.iainbukittinggi.ac.id/index.php/educative/article/view/118/62.

Nurparida, \& Srirahayu, E. (2021). Efektivitas Media Audio Visual dalam Meningkatkan Hasil Belajar Siswa pada Pembelajaran IPS Terpadu Kelas VII MTS. Al Yusufiah. Jurnal Ilmu Sosial Dan Pendidikan, 5(1), 155-162. Retrieved from http://ejournal.mandalanursa.org/index.php/JISIP/article/view/1628/1452.

Nurrohma, R. I., \& Adistana, G. A. Y. P. (2021). Penerapan Model Pembelajaran Problem Based Learning dengan Media E-Learning Melalui Aplikasi Edmodo pada Mekanika Teknik. Jurnal Ilmu Pendidikan, 3(4), 1199-1209. Retrieved from https://www.edukatif.org/index.php/edukatif/article/view/544/pdf.

Pradilasari, L., Gani, A., \& Khaldun, I. (2019). Pengembangan Media Pembelajaran Berbasis Audio Visual pada Materi Koloid untuk Meningkatkan Motivasi dan Hasil Belajar Siswa SMA. Jurnal Pendidikan Sains Indonesia, 7(1), 9-15. https://doi.org/10.24815/jpsi.v7i1.13293.

Prasedari, L. P. E., Pujdawan, K., \& Suranata, K. (2019). Pengaruh Model Pembelajaran Problem Based Learning Berorientasi Tri Hita Karana Terhadap Hasil Belajar Matematika Siswa Kelas IV. Jurnal Pendidikan Multikultural Indonesia, 2(2), 50-60. https://doi.org/10.23887/jpmu.v1i2.20771.

Putra, I. K. D. A. S., Margunayasa, I. G., \& Wibawa, I. M. C. (2017). Pengaruh Model Pembelajaran Inkuiri Terbimbing Berbantuan Peta Pikiran Terhadap Hasil Belajar IPA Kelas V SD. Mimbar PGSD Undiksha, 5(2), 1-10. Retrieved from https://ejournal.undiksha.ac.id/index.php/JJPGSD/article/view/10711/6814.

Rahman, A., Khaeruddin, \& Ristiana, E. (2020). Pengaruh Model PBL Terhadap Kemampuan Berpikir Kritis dan Pemahaman Konsep IPA Siswa Kelas V SDN 30 Sumpangbita. Edumaspul: Jurnal Pendidikan, 4(1), 29-41. Retrieved from https://ummaspul.e-journal.id/maspuljr/article/view/201/165.

Sa'ria, S., Syuba, F., \& Ngazizah, N. (2021). Penilaian Keterampilan Proses Siswa dalam 
Pembelajaran Daring. Jurnal Pendidikan Dasar, 3, 1-14. Retrieved from http://eproceedings.umpwr.ac.id/index.php/semnaspgsd/article/view/1607/1462.

Safrida, M., \& Kistian, A. (2020). Penerapan Model Pembelajaran Problem Based Learning (PBL) untuk Meningkatkan Hasil Belajar IPA Kelas V SD Negeri Peureumeue Kecamatan Kaway XVI. Bina Gogik, 7(1), 53-65. Retrieved from https://ejournal.stkipbbm.ac.id/index.php/pgsd/article/view/433.

Sanjaya, W. (2016). Penelitian Tindakan Kelas. Jakarta: Prenada Media.

Suprianto, E. (2020). Implementasi Media Audio Visual untuk Meningkatkan Kemampuan Menulis Teks Eksplanasi. Trapsila: Jurnal Pendidikan Dasar, 1(02), 22. https://doi.org/10.30742/tpd.v1i02.810.

Tias, I. W. U. (2017). Penerapan Model Penemuan Terbimbing untuk Meningkatkan Hasil Belajar IPA Siswa Sekolah Dasar. Dwija Cendekia Jurnal Riset Pedagogik, 1(1), 5060. https://doi.org/10.20961/jdc.v1i1.13060.

Yasmini, I. G. K. (2021). Penerapan Model Pembelajaran Problem Based Learning untuk Meningkatkan Motivasi dan Hasil Belajar Biologi Siswa. Journal of Education Action Research, 5(2), 159-164. https://doi.org/10.31764/justek.v2i1.3710. 